\title{
Recycling of Waste Tea Leaves via Vermicomposting Process and the Effect on Water Spinach Growth
}

\author{
M. S. M. Zaini* and W. A. Syafi \\ School of Chemical Engineering, College of Engineering, Universiti Teknologi MARA, \\ Cawangan Terengganu, Kampus Bukit Besi, 23200 Dungun, Terengganu, Malaysia
}

https://doi.org/10.15255/KUI.2020.065

KUI-27/2021

Original scientific paper

Received September 28, 2020

Accepted November 23, 2020

\begin{abstract}
Vermicomposting is a bio-composting process in which earthworms are used to enhance the conversion of organic waste to produce better end-product. This study was conducted to investigate the vermicomposting process via earthworm (Eisenia feotida) using waste tea leaves as feedstock and bedding material. The matured vermicompost was obtained after 10 weeks of vermicomposting process. The earthworm population and mass of bedding were monitored weekly. The condition of bedding material was analysed daily. During the vermicomposting process, the temperature increased within mesophilic phase between $23{ }^{\circ} \mathrm{C}$ and $28{ }^{\circ} \mathrm{C}$. The $\mathrm{pH}$ of vermicompost ranged between 6.5 and 7.7. The matured vermicompost and commercial soil were compared for the plant growth trial for 3 weeks of the study. The results showed that the combination of matured waste tea leaves vermicompost and commercial soil generated the highest growth compared to the commercialised soil alone. This indicated that vermicompost contained rich nutrients that assisted the plant growth effectively.
\end{abstract}

\section{Keywords}

Vermicompost, tea waste, $\mathrm{pH}$, plant growth, population

\section{Introduction}

Tea is one of the most consumed beverages in the world due to its advantages for human health. Most tea types originate from the same basic plant, which is the Camellia sinensis plant. The difference between teas arises from geography, climate conditions, growing conditions, and processing. ${ }^{1}$ The Camellia sinensis plant is native to East Asia, originating in the borderlands of north Burma and south-western China, but it is currently planted around the world in tropical and subtropical areas with over 3000 varieties of tea. Tea can be divided into six types, known as black, dark, oolong, yellow, white, and green tea.

Tea waste or beverage tea is well known for containing high amounts of polyphenols, especially flavanols or catechins. The extraction of fresh tea leaf in water contains polyphenols, particularly flavanols, flavanol gallate, and flavanol glycosides. ${ }^{2}$ One of the major components in tea are catechins. Catechins are strong antioxidants due to the presence of $\alpha$-epigallocatechin-3-gallate (EGCG), $\alpha$-epigallocatechin (EGC), $\alpha$-epicatechin-3-gallate (ECG), $\alpha$-epicatechin (EC), $\alpha$-gallocatechin, and $\beta$-catechin; constituting approximately $42 \%$ of the green tea solids by weight. Tea has high benefits for human health - it prevents tumour cell growth, reduces cardiovascular diseases, reduces cholesterol, and induces body weight loss. ${ }^{3}$ One of the advantages of tea is that it has high antioxidant properties due to the presence of flavonoid components, such as theaflavins, bisflavanols, and theaflavic acids, and acts as a free radical scavenger. ${ }^{2}$

*Corresponding author: Mohd Saufi Md Zaini, CEng, MIChemE, MEng(Sheffield), MSc(UiTM), Email: saufizaini@uitm.edu.my
Malaysia is blessed with fertile soil, abundant rainfall, and suitable climate for production of tea. The largest production of tea is primarily in the Cameron Highlands region. Cameron Highlands, sometimes referred to as the "Green Bowl", are located 1.500 meters above sea level, where the conditions are regarded as ideal for the production of robust, flavourful, and aromatic teas. The production of tea in Malaysia is about $0.45 \%$ of the world's total tea production. According to the Food and Agriculture Organisation of United Nation, in 2011, Malaysia was the $18^{\text {th }}$ largest producer of tea in Asia. ${ }^{4}$ The largest tea producer company in Malaysia, known as $\mathrm{BOH}$ plantation, has approximately 12000 hectares of tea plantations. $\mathrm{BOH}$ alone produces approximately $70 \%$ of total production in Malaysia, $90 \%$ is reserved for local consumers, and the balance is exported to other countries. Total tea consumption in Malaysia reached $33.7 \mathrm{Kt}$ in 2013, and is expected to rise $50 \%$ in 2020. ${ }^{5}$ Malaysia has been ranked $26^{\text {th }}$ out of 154 countries of total tea consumption in the world. Without a doubt, tea is one the favourite drinks in Malaysia. Despite its attractiveness, there are issues concerning the disposal of tea waste post extraction. The massive generation of waste either from consumers or from industry will undoubtedly lead to environmental problems associated with improper disposal. In addition, lack of sustainable waste management practices will result in further issues. Vermicompost is one of the practical methods for degrading tea waste sustainably. ${ }^{6}$

Vermicomposting is a cost-effective biodegradation process for converting organic waste into humus-like material in a sustainable way. It involves oxidation and stabilisation of the organic waste by earthworms and microorganisms, converting it into nutrient-rich vermicompost. The qual- 
ity of vermicompost relies on suitable temperature and humidity conditions of the organic waste. Compost teas supply microbial biomass, fine particulate organic matter, organic acids, plant growth regulator like substances, and soluble mineral nutrients to plant surfaces and soils. ${ }^{8}$ Many researchers have been devoted to converting tea leaves into vermicompost teas for soil fertiliser. For example, Mahaly et al. ${ }^{9}$ combined tea leaf residue with distillery sludge waste and performed the vermicomposting process. They succeeded in converting these organic wastes into nutrient-rich vermicast. On the other hand, C. Edwards et al. ${ }^{10}$ investigated the impact of tea leaf vermicompost in suppressing plant parasite nematodes and arthropods. They found that plants fertilised with tea vermicast had a strong resilience to parasites, and grew more successfully. Meanwhile, Fritz et al. ${ }^{11}$ employed the vermicomposting process on tea leaves to study the microbiological analysis and its influence on wheat, barley, and vegetables growth. The ultimate goal in these studies was to obtain the effect on the crop yield in field-scale experiment using tea vermicast. They observed that vermicompost tea was beneficial to plant growth, and induced microbial activity and diversity. However, no study to date has reported the vermicomposting of post-consumption tea leaves for water spinach growth trial. Thus, this paper aims to provide thorough understanding of the potential production of vermicompost from waste tea leaves using Eisenia fetida earthworms and plant growth trial. The uses of waste tea leaves in this study may provide an additional understanding into production of good fertiliser. The comparison between commercial soil and the mixture of vermicompost + commercial soil were also made for growth trial of water spinach.

\section{Materials and methods}

\subsection{Materials preparation}

Eisenia fetida earthworm was selected as vermicomposting agent due to its ability to tolerate a wide range of temperature and humidity. The tea $\mathrm{BOH}$ waste was obtained from the cafeteria of Universiti Tekonolgi MARA, Kampus Bukit Besi. It was washed with distilled water and dried overnight. The experiment was conducted in a small scale. Washed tea waste was placed in a small container densely perforated to provide enough aeration respiration. An amount of $100 \mathrm{~g}$ of tea waste was used as feedstock and bedding for earthworms. The earthworms were placed in the container and the feedstock was sprinkled with tap water daily to maintain moisture content. The container was kept in the dark place to resemble the natural habitat of earthworms. The duration of vermicomposting process was 8 weeks, and subsequently the matured vermicompost underwent plant growth trial for another 3 weeks. The vermicompost was collected every week, and its chemical characteristics analysed. The mass and population of earthworms were recorded every two weeks. The earthworms were separated from the tea waste by hand, and then the tea and the earthworms were weighed. ${ }^{12}$

\subsection{Chemical analysis}

The $\mathrm{pH}$ was measured using HACH HQ40D portable multi meter and OHAUS Model ST300 portable pH meter. Conductivity was measured using the same instrument of $\mathrm{HACH}$ HQ40D portable multi meter. Both $\mathrm{pH}$ and conductivity were measured daily. The samples were immersed in distilled water for about $5 \mathrm{~min},{ }^{13}$ then the meter was inserted into immersed sample, and these measurements were repeated for 56 days ( 8 weeks). The temperature was monitored daily using digital traceable thermometers. The probe was inserted at $50 \mathrm{~mm}$ depth in the vermicompost and the readings recorded. ${ }^{14}$

\subsection{Growth trial}

The growth trial experiment was conducted by germination of water spinach (Ipomoea aquatica) seeds for three weeks. The growth of water spinach was investigated using commercialised soil and a mixture of commercialised soil and vermicompost (as booster). The water spinach seed was sown in a seed tray (width $23 \mathrm{~cm}$, depth $36 \mathrm{~cm}$, height $5.5 \mathrm{~cm}$, size 24 cells). Each sample was replicated twice (shown as numbers 1 and 2) and divided into 4 batches, as shown in Table 1. The media were sprayed with distilled water three times a week. The seedlings were relocated to a pot after two weeks of germination. The heights of the plants were recorded every week using a measuring tape.

\section{Results and discussions}

\subsection{Mass of tea waste and earthworms}

The growth of earthworms is one of the indicators for evaluating the progress of vermicomposting process. According

Table 1 - Sample name, media, and plant growth trial

\begin{tabular}{c|c|c|c}
\hline No. & Sample name & Media & Plant \\
\hline 1 & CS A $\left(1^{*}\right)$ & commercial soil & water spinach \\
\hline 2 & CS A $\left(2^{*}\right)$ & commercial soil & water spinach \\
\hline 3 & $50 \%$ VC $+50 \%$ CS A $\left(1^{*}\right)$ & $50 \%$ vermicompost $+50 \%$ commercial soil & water spinach \\
\hline 4 & $50 \%$ VC $+50 \%$ CS A $(2 *)$ & $50 \%$ vermicompost $+50 \%$ commercial soil & water spinach \\
\hline
\end{tabular}

* 1 and 2 indicate trials 1 and 2 


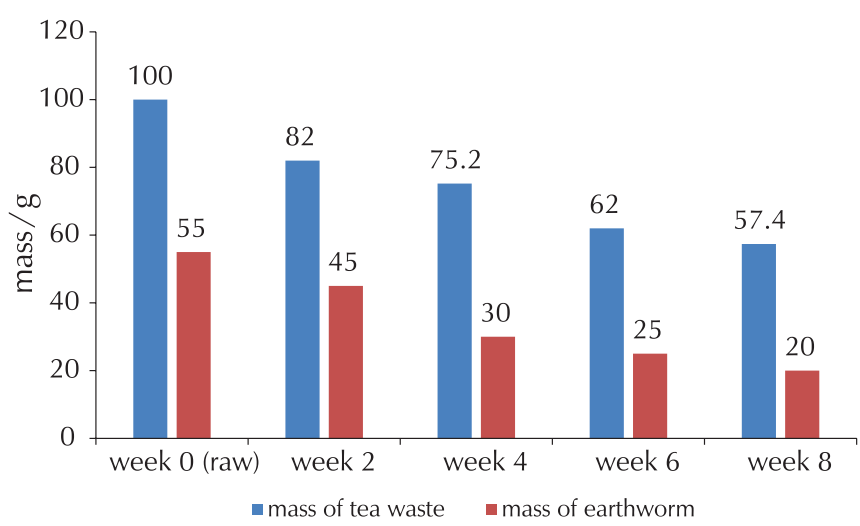

Fig. 1 - Mass of total tea waste and earthworms during vermicomposting process

to Gupta et al., ${ }^{15}$ the growth of vermicomposting agent is closely related to the feedstock quality. In this study, the highest weight of earthworm recorded was 58 g. Fig. 1 also shows the mass of tea leaves during vermicomposting process. Plentiful food available at the beginning of vermicomposting process boosted the rate of vermicomposting process and increased the growth of microbial community, thus producing high quality vermicompost. As may be seen from Fig. 1, both mass of tea waste and earthworm biomass showed declination patterns afterward. Almost $50 \%$ of tea waste was consumed after 8 weeks of process. This indicated that the waste was easily degradable and an ideal organic substance for conversion into vermicompost. These results are consistent with the results obtained by Ndegwa et al. ${ }^{16}$ It was also noted that, at the end of vermicomposting process, the population of earthworms decreased significantly. Many earthworms were found dead due to the conversion of tea waste as food into vermicompost, and competition raised by many other earthworms. ${ }^{17,18}$

\subsection{Temperature analysis}

Temperature is one of the factors affecting the metabolism, growth, and reproduction of worms. According to Abbasi et al., ${ }^{19}$ earthworms maintain lower body temperatures than the surrounding soil or organic matter by their metabolic adjustments. In this study, the bedding temperature of tea waste was not much different throughout the process period (Fig. 2). The lowest temperature of bedding was $20^{\circ} \mathrm{C}$, while the highest temperature was $28^{\circ} \mathrm{C}$. This temperature is suitable for earthworms to thrive and reproduce because the optimal temperature for E. Fetida is $25{ }^{\circ} \mathrm{C}$, and cannot tolerate temperatures above $35{ }^{\circ} \mathrm{C} .{ }^{20}$ Thus, in this study, the bedding conditions were regarded as ideal for the growth and activity of earthworms. The fluctuation of temperature occurred due to the turning, fragmentation, and aeration process by earthworms. Furthermore, tea waste was sprayed with water daily in order to maintain the proper moisture content, which subsequently affected the bedding temperature.

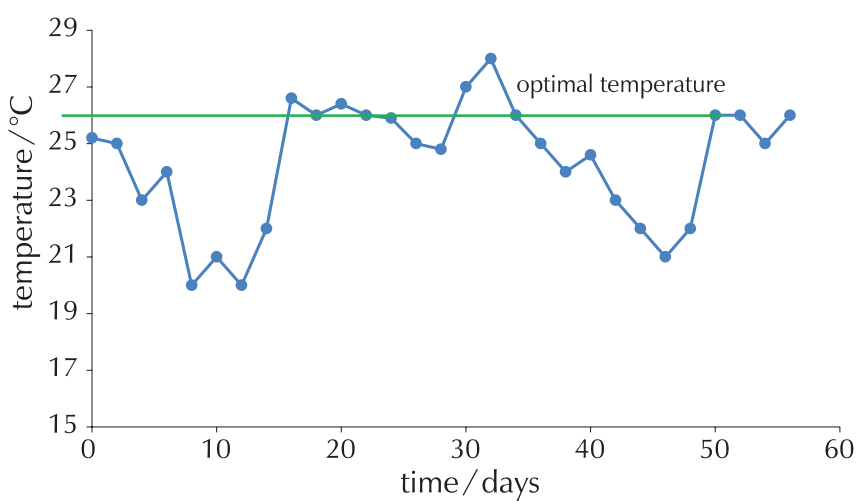

Fig. 2 - Bedding temperature during vermicomposting process

\section{$3.3 \mathrm{pH}$ Analysis}

The $\mathrm{pH}$ is one of the factors that affect the metabolism of earthworms. As shown in Fig. 3, the $\mathrm{pH}$ of initial product slightly increased due to the formation of ammonium ions $\left(\mathrm{NH}_{4}{ }^{+}\right)$through incentive mineralisation of nitrogen by microbes. The value of $\mathrm{pH}$ showed fluctuation afterwards, but the trend of the fluctuation favoured to shift towards neutrality. The decomposition process produced organic acid resulting in acidic conditions. ${ }^{21}$ On the other hand, during decomposition of organic matter, the hydrogen ions were also released due to nitrification process. Both nitric acid and ammonium ion contributed to the fluctuation of $\mathrm{pH}$ afterward that buffered the $\mathrm{pH}$. Matured vermicompost showed neutral $\mathrm{pH}$, i.e., 7.4. According to Singh et al., ${ }^{22}$ the ideal $\mathrm{pH}$ for E. Fetida is between 7 and 8. Thus, it was concluded that the $\mathrm{pH}$ media in this experiment was in good condition for earthworms to thrive.

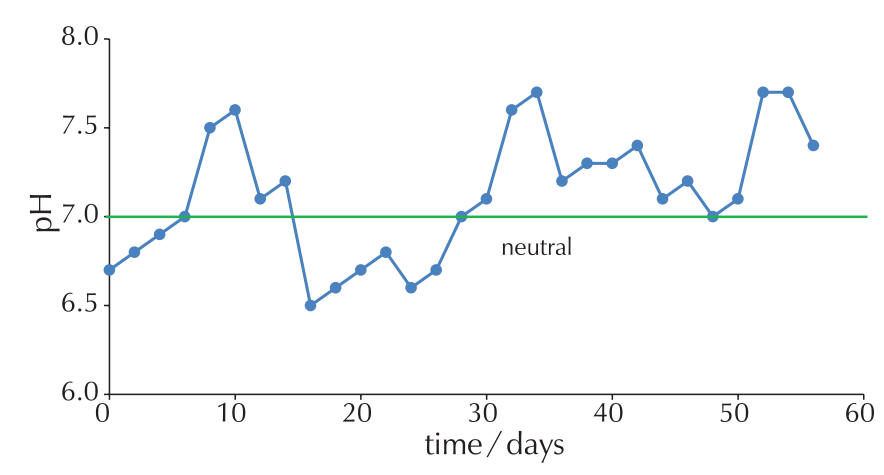

Fig. 3 - Bedding $\mathrm{pH}$ during vermicomposting process

\subsection{Electrical conductivity analysis}

Electrical conductivity (EC) is the amount of dissolved salts released or the total amount of ions dissolved in the water during the decomposition of organic substances. ${ }^{23} \mathrm{EC}$ depends on the raw material used for vermicomposting, since it is related to their ion exchange. ${ }^{24}$ Fig. 4 shows the variation of electrical conductivity for used tea leaves dur- 
ing vermicomposting process. The graph shows fluctuation pattern of electrical conductivity. The fluctuation of electrical conductivity occurred due to earthworm activity. ${ }^{25}$ The increase in electrical conductivity was mainly due to loss of weight during the decomposition of organic substance, and as a result, it released other mineral ions such as phosphate and ammonium ion in the product. ${ }^{17}$ The reduction of EC occurred because of the volatilisation of ammonia and precipitation of other mineral salts, as reported by Wong et al. ${ }^{26}$

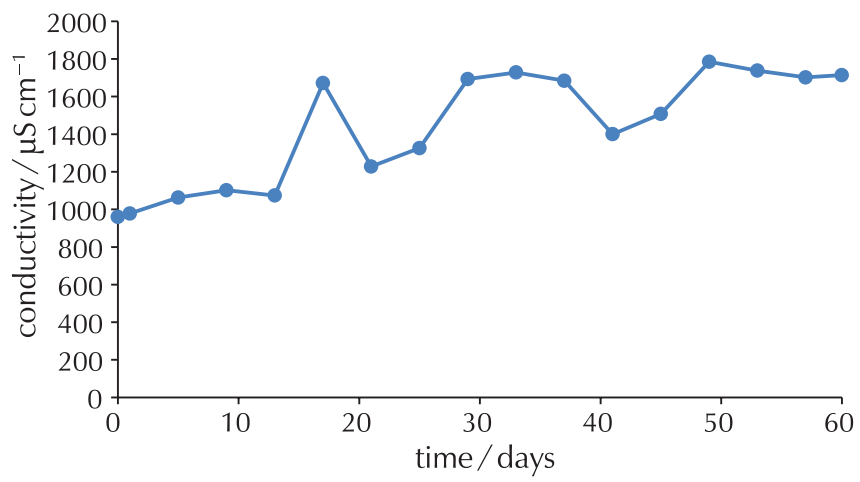

Fig. 4 - Fluctuation of electrical conductivity during vermicomposting process

\subsection{Growth trial}

A growth trial was conducted to determine the effect of vermicompost on the plant. The performance of growth was measured in terms of plant height in 3 weeks. Fig. 5 represents the height of water spinach (Ipomoea aquatica) at different treatments with time. There were two batches of soil - commercial soil (control), and $50 \%$ commercial soil (CS) + 50 \% vermicompost (VC). Each of the samples were replicated twice to increase the accuracy of the result. Overall, all the plants showed height increase in 3 weeks of experiment. However, the combination of $50 \%$ CS and $50 \%$ VC showed more significant growth than that of the control. The maximum height was observed in $50 \%$ $\mathrm{CS}+50 \% \mathrm{VC}(1)$ which was $4.2 \mathrm{~cm}$.

Tea leaves contain many minerals. During the "brewing" process, the soluble mineral nutrients, beneficial microorganisms, and humic acid were extracted from the tea leaves. These substances are the key factor that positively affect plant growth activity. According to M. Iannotti, ${ }^{27}$ used tea contains three important nutrients (nitrogen, phosphorous, and potassium), as well as some trace minerals. These minerals stimulate plant growth. Keeling et al. ${ }^{28}$ reported that vermicompost tea acts as soil booster to oilseed rape plants, especially at the initial stage of growth, since it enhances root development. In addition, vermicompost using waste tea leaves will speed the breakdown of toxins surrounding the plant, and increase the porosity and microbial activity in soil, which subsequently improves soil quality, maintaining moisture and increasing the oxygen levels and even allowing earthworms to thrive. ${ }^{29}$ In other words, tea compost is a good way to support plant health, prevent pest infestations, and stave off disease. Based on the previous results and discussion, it was concluded that waste tea leaves had high potential for converting into a good quality vermicompost.

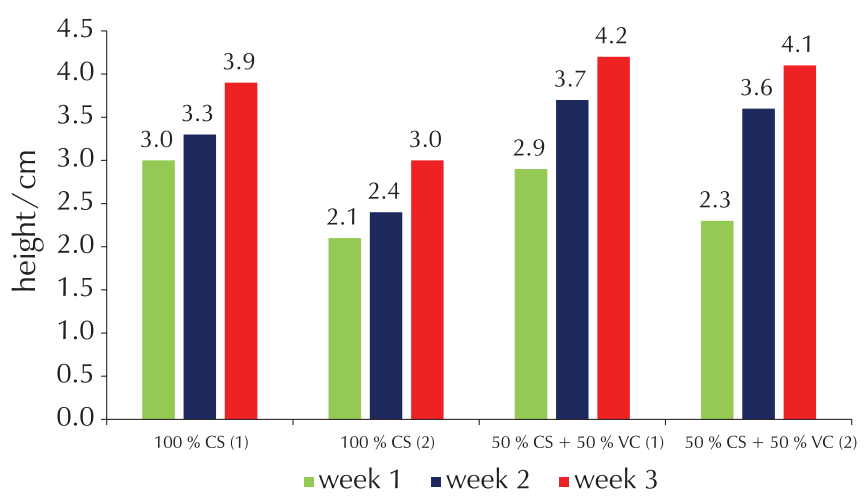

Fig. 6 - Three-week growth trial

\section{Conclusion}

In the present study, waste tea leaves were successfully converted as feedstock into vermicompost using Eisenia fetida earthworms. At the end of the vermicomposting process, there was an increase in temperature, and $\mathrm{pH}$ shifted toward alkalinity. The increase in conductivity proved that organic substances of tea leaves decomposed into valuable mineral ions. Combination of $50 \%$ CS + 50 VC had significant effect on the growth of water spinach compared to that using CS alone. This shows that waste tea leaves have good potential as soil fertiliser precursors.

\section{References \\ Literatura}

1. A. P. Pant, T. J. K. Radovich, N. V. Hue, R. E. Paull, Biochemical properties of compost tea associated with compost quality and effects on pak choi growth, Sci. Hortic. (Amsterdam). 148 (2012) 138-146, doi: https://doi.org/10.1016/j.scienta.2012.09.019.

2. Y. H. Kim, J. Bowers, Health benefits of tea, Altern. Ther. Womens Heal. 10 (2008) 9-12, URL: https://www.reliasmedia.com/articles/9530-health-benefits-of-tea.

3. M. Fadzelly, Phytochemicals and antioxidant properties of different parts of Camellia sinensis leaves from Sabah Tea Plantation in Sabah, Malaysia, Int. Food Res. J. 20 (2013).

4. K. Mansur, Tea Production in Malaysia: Culture versus Challenges and Prospect to Malaysian Economics, Int. J. Res. Innov. Soc. Sci. (IJRISS) 3 (6) (2019) 324-328, URL: https:// www.rsisinternational.org/journals/ijriss/Digital-Library/volume-3-issue-6/324-328.pdf.

5. Tea Consumption (Total) in Malaysia, Helgi Library, URL: https://www.helgilibrary.com/indicators/tea-consumption-total/malaysia/.

6. A. M. Yatoo, S. Rasool, S. Ali, S. Majid, M. U. Rehman, Md. N. Ali, R. Eachkoti, S. Rasool, S. M. Rashid, S. Farooq, Vermicomposting: An Eco-Friendly Approach for Recycling/Management of Organic Wastes, in: K. Hakeem, R. Bhat, H. Qadri (Eds) Bioremediation and Biotechnology, Springer, Cham, 
2020, pp. 167-187, doi: https://doi.org/10.1007/978-3030-35691-0_8.

7. J. H. Al-Dahmani, P. A. Abbasi, S. A. Miller, H. A. J. Hoitink, Suppression of bacterial spot of tomato with foliar sprays of compost extracts under greenhouse and field conditions, Plant Dis. 87 (2003) 913-919, doi: https://doi.org/10.1094/ PDIS.2003.87.8.913.

8. C. A. Edwards, N. Q. Arancon, S. Greytak, Effects of Vermicompost Teas on Plant Growth and Disease, https://www. growingsolutions.com/wp-content/uploads/2015/02/Edwards2006.pdf (2006).

9. M. Mahaly, A. K. Senthilkumar, S. Arumugam, C. Kaliyaperumal, N. Karupannan, Vermicomposting of distillery sludge waste with tea leaf residues, Sustain. Environ. Res. 28 (2018) 223-227, doi: https://doi.org/10.1016/j.serj.2018.02.002.

10. C. A. Edwards, N. Q. Arancon, E. Emerson, R. Pulliam, Suppressing plant parasitic nematodes and arthropod pests with vermicompost teas, (2007) 38-39.

11. J. I. Fritz, S. Haindl, H. Insam, R. Braun, Microbiological community analysis of vermicompost tea and its influence on the growth of vegetables and cereals, Can. J. Microbiol. 58 (2012) 836-847, doi: https://doi.org/10.1139/w2012-061.

12. M. Zarei, V. A. J. M. Abadi, A. Moridi, Comparison of vermiwash and vermicompost tea properties produced from different organic beds under greenhouse conditions, Int. J. Recycl. Org. Waste Agric. 7 (2018) 25-32, doi: https://doi. org/10.1007/s40093-017-0186-2.

13. L. Abbey, S. A. Rao, L. N. Hodgins, F. Briet, Drying and Rehydration of Vermicasts Do Not Affect Nutrient Bioavailability and Seedling Growth, Amer. J. Plant Nutr. Fertil. Technol. 3 (2012) 12-21, doi: https://doi.org/10.3923/ajpnft.2013.12.21.

14. Y. Indrani, R. Abdullah, A. Ansari, L. Ori, Vermicomposting of different organic materials using the epigeic earthworm Eisenia foetida, Int. J. Recycl. Org. Waste Agric. 8 (2019) 23-36, doi: https://doi.org/10.1007/s40093-018-0225-7.

15. V. K. Garg, R. Gupta, Optimization of cow dung spiked pre-consumer processing vegetable waste for vermicomposting using Eisenia fetida, Ecotoxicol. Environ. Saf. 74 (2011) 19-24, doi: https://doi.org/10.1016/j.ecoenv.2010.09.015.

16. P. M. Ndegwa, S. A. Thompson, K. C. Das, Effects of stocking density and feeding rate on vermicomposting of biosolids, Bioresour. Technol. 71 (2000) 5-12, doi: https://doi. org/10.1016/S0960-8524(99)00055-3.

17. S. Sharma, P. Vasudevan, K. Pradhan, S. Satya, Potentiality of Earthworms for Waste Management and in Other Uses-A Review, J. Am. Sci. 1 (2005) 4-16.

18. M. S. M. Zaini, S. S. A. Syed-Hassan, Comparative Effects of Activation by $\mathrm{CO}_{2}$, Steam and Their Sequential Combinations on the Pore Structure of Carbon Material Produced from $\mathrm{ZnCl}_{2}$-Treated Oil Palm Kernel Shell, Recent Innov.
Chem. Eng. (Formerly Recent Patents Chem. Eng. 11 (2018) 50-59, doi: https://doi.org/10.2174/240552041166618042 7112212 .

19. S. A. Abbasi, M. Nayeem-Shah, T. Abbasi, Vermicomposting of phytomass: Limitations of the past approaches and the emerging directions, J. Clean. Prod. 93 (2015) 103-114, doi: https://doi.org/10.1016/j.jclepro.2015.01.024.

20. P. N. Lim, T. Y. Wu, C. Clarke, N. N. Nik Daud, A potential bioconversion of empty fruit bunches into organic fertilizer using Eudrilus eugeniae, Int. J. Environ. Sci. Technol. 12 (2015) 2533-2544, doi: https://doi.org/10.1007/s13762014-0648-2.

21. C. Tognetti, M. J. Mazzarino, F. Laos, Cocomposting biosolids and municipal organic waste: Effects of process management on stabilization and quality, Biol. Fertil. Soils 43 (2007) 387-397, doi: https://doi.org/10.1007/s00374-006-0164-8.

22. N. B. Singh, A. K. Khare, D. S. Bhargava, S. Bhattacharya, Effect of Initial Substrate $\mathrm{pH}$ on Vermicomposting using Perionyx excavatus (PERRIER, 1872), Appl. Ecol. Environ. Res. 4 (1) (2005) 85-97, doi: https://doi.org/10.15666/ aeer/0401_085097.

23. M. Ali, Quality enhancement of compost using vermicomposting and air separation, PhD Thesis, Cardiff University, 2007, URL: http://orca.cf.ac.uk/54691/1/U585080.pdf.

24. R. M. Atiyeh, S. Lee, C. A. Edwards, N. Q. Arancon, J. D. Metzger, The influence of humic acids derived from earthworm-processed organic wastes on plant growth, Bioresour. Technol. 84 (1) (2002) 7-14, doi: https://doi.org/10.1016/ s0960-8524(02)00017-2.

25. B. Gunadi, C. A. Edwards, The effects of multiple applications of different organic wastes on the growth, fecundity and survival of Eisenia fetida (Savigny) (Lumbricidae), Pedobiologia (Jena) 47 (2003) 321-329, doi: https://doi. org/10.1078/0031-4056-00196.

26. J. W. CWong, K. F. Mak, N. W. Chan, A. Lam, M. Fang, L. X. Zhou, Q. T.Wu, X. D. Liao, Co-composting of soybean residues and leaves in Hong Kong, Bioresour. Technol. 76 (2) (2000) 99-106, doi: https://doi.org/10.1016/S09608524(00)00103-6.

27. M. Iannotti. Great Soil Enhancement, URL: https://www. thespruce.com/used-tea-leaves-make-great-soil-1403136 (17. 9. 2020).

28. A. A. Keeling, K. R. McCallum, C. P. Beckwith, Mature green waste compost enhances growth and nitrogen uptake in wheat (Triticum aestivum L.) and oilseed rape (Brassica napus L.) through the action of water-extractable factors, Bioresour. Technol. 90 (2003) 127-132, doi: https://doi.org/10.1016/ S0960-8524(03)00125-1.

29. J. Pathma, N. Sakthivel, Microbial diversity of vermicompost bacteria that exhibit useful agricultural traits and waste management potential, SpringerPlus 1 (2012) 1-19, doi: https:// doi.org/10.1186/2193-1801-1-26. 


\section{SAŽETAK \\ Recikliranje otpadnog lišća čaja postupkom vermikompostiranja i utjecaj na rast špinata u vodi

\author{
Mohd Saufi Md Zaini* i Wan Adri Syafi
}

Vermikompostiranje je postupak biokompostiranja u kojem se gliste upotrebljavaju za pojačanu pretvorbu organskog otpada u bolji krajnji proizvod. Ovo je istraživanje provedeno da bi se istražio postupak vermikompostiranja pomoću gliste (Eisenia feotida) uporabom otpadnog lišća čaja kao sirovine i podložnog materijala. Sazreli vermikompost dobiven je nakon 10 tjedana postupka vermikompostiranja. Populacija glista i masa podložnog materijala pratili su se tjedno. Stanje podložnog materijala analiziralo se svakodnevno. Tijekom procesa vermikompostiranja temperatura se povećavala unutar mezofilne faze između $23{ }^{\circ} \mathrm{C}$ i $28{ }^{\circ} \mathrm{C}$. pH vrijednost vermikomposta kretao se između 6,5 i 7,7. Zreli vermikompost i komercijalno tlo uspoređivani su za ispitivanje rasta biljaka tijekom 3 tjedna studije. Rezultati su pokazali da je kombinacija dozrelog otpadnog lišća čaja vermikomposta i komercijalnog tla generirala najveći rast u usporedbi samo s komercijaliziranim tlom. To je ukazivalo da vermikompost sadrži bogate hranjive sastojke koji učinkovito pomažu biljnom rastu.

Ključne riječi

Vermikompost, čajni otpad, pH, rast biljaka, populacija

School of Chemical Engineering

College of Engineering

Universiti Teknologi MARA

Cawangan Terengganu, Kampus Bukit Besi

23200 Dungun, Terengganu, Malezija
Izvorni znanstveni rad Prispjelo 28. rujna 2020. Prihvaćeno 23. studenoga 2020. 